\title{
Changes in the Use of Agricultural Land in Poland and Czech Republic
}

\author{
Agnieszka Stacherzak', Ladislav Hájek², Maria Hełdak \\ 1 Wrocław University of Environmental and Life Sciences, Department of Spatial Economy, ul. Grunwaldzka 55, \\ 50-357 Wrocław, Poland \\ 2 University of Hradec Králové, Faculty of Informatics and Management, Economics Department, \\ Hradecká 1249/6, Hradec Králové, building J, Czech Republic \\ * Corresponding author's e-mail: maria.heldak@upwr.edu.pl
}

\begin{abstract}
This article raises the issue of changes in the structure of agricultural land use in Poland and the Czech Republic since the accession of both countries into the structures of the European Union. An important question raised in this article is the analysis of changes in the area structure of agricultural holdings according to the adopted agricultural land groups. The analyses were based on the graphic method of analysing the concentration strength, i.e. the Lorenz curve, to determine the distribution of the number and surface area of agricultural farms in the given area groups and the percentage share of such farms in these area groups. Additionally, the Gini coefficient was calculated for the same phenomena, to measure the concentration (inequality) of the random variable distribution. The research showed the structural change trends in the agricultural area of the analysed countries as well as varied structural situation of agricultural holdings during the accession period. The condition translates into a slower pace of structural change of agricultural holdings in Poland and a faster process of enlarging the area of agricultural holdings in the Czech Republic.
\end{abstract}

Keywords: agricultural land, Poland, Czech Republic, agricultural holdings.

\section{INTRODUCTION}

The landscape of Eastern Europe has undergone dramatic changes in many respects [Bičík and Štěpánek, 1994; Lipský, 1995; Lorincz and Balazs, 2002; Opršal et al., 2013]. The changes refer, in particular, to the agricultural land and follow, inter alia, the transformation from the centrally governed economy of the post-communist countries into free market economy. Additionally, following the Poland and Czech Republic accession into the structures of the European Union, they are the result of farming policy of particular countries and the European Union.

As stated by Sadowski [2009], the post-communist countries, including Poland and the Czech Republic, underwent systemic transformations in the last decade of the twentieth century that substantially influenced the structure of agriculture.
In the new political reality, new rules were defined and bodies which represented State Treasury were established, because a substantial part of agricultural land was state property. In Poland, the Treasury Agricultural Property Stock was established as a body managing this Stock; today, it is the National Support Centre for Agriculture (NSCA). This agency (NSCA) was established on the 1st September 2017, pursuant to the Act of 10th February 2017. Two agricultural agencies ceased to exist on that date: The Agricultural Market Agency and The Agricultural Property Agency

In the countries such as Czech Republic, Estonia, Latvia, Lithuania, Slovakia or Hungary, the situation was different. Despite being a part of the same centrally-governed economies bloc, the agricultural land in those countries was shared between cooperatives and state-owned holdings [Sarris i in., 2000; Swinnen, 2001; Lerman et al., 2002, Poczta (Ed.), 2013]. 
In Czech and Slovak agriculture, the form of large scale farms was, to a certain degree, preserved, although there was a change of ownership or users of the holdings.

Significant factors influencing the change of use of agricultural land are the changes in the employment structure in rural areas and resignation from land cultivation as a result of lack of profitability of field production.

Farming is concentrated in more fertile areas, whereas in agriculturally marginal areas, there is a transition to less intensive forms of land use [Opršal et al., 2013].

The changes in land cover also relate to these factors - as confirmed in a study by Balej (2008), and Druga (2014), which confirmed a transition from arable land to grassland in the areas of higher altitudes, with steeper gradient and worse soil quality.

Subsequent research including the selected socio-economic factors [Hietel et al., 2005] confirmed that land use changes result from the combined influence of the environmental and socioeconomic factors, which are in mutual interaction. A new performance-oriented direction of enterprise management, is connected to the transfer from static models to dynamic ones, flexibly reacting to the changes in business environment [Faltejsková et al., 2016]. Globalization can influence economies in the transformation in a variety of ways [Kriřan et al., 2016; Rumpel et al., 2013; Urbšiene, 2013; Jarmołowicz and Piątek, 2013].

The aim of the research was to illustrate the changes that the agricultural land of the chosen EU countries underwent as well as the analysis of changes in the area structure of agricultural holdings in Poland and Czech Republic and in the number of holdings in agricultural land groups. The aim is forecasting the directions of further change in the structure and the transition of agricultural land in those countries.

\section{METHODOLOGY}

The changes in the organisational structure of the utilised agricultural land and agricultural holdings were analysed in Poland and the Czech Republic (fig. 1). Both countries are located Central-Eastern Europe and they share the border of a distance approx. $796 \mathrm{~km}$. At the end of 2014, there were 38.483.957 citizens living in Poland (in 2015 - 38.437.239); whereas the Czech Republic had 10.538.275 citizens (in $2015-10.542 .942$ ).

These countries joined in the structures of the European Union in 2004. In both countries, there are many factors influencing the area of farming as well as the structure of agricultural holdings and utilised agricultural land, inter alia: integration with the European Union and common farming policy,

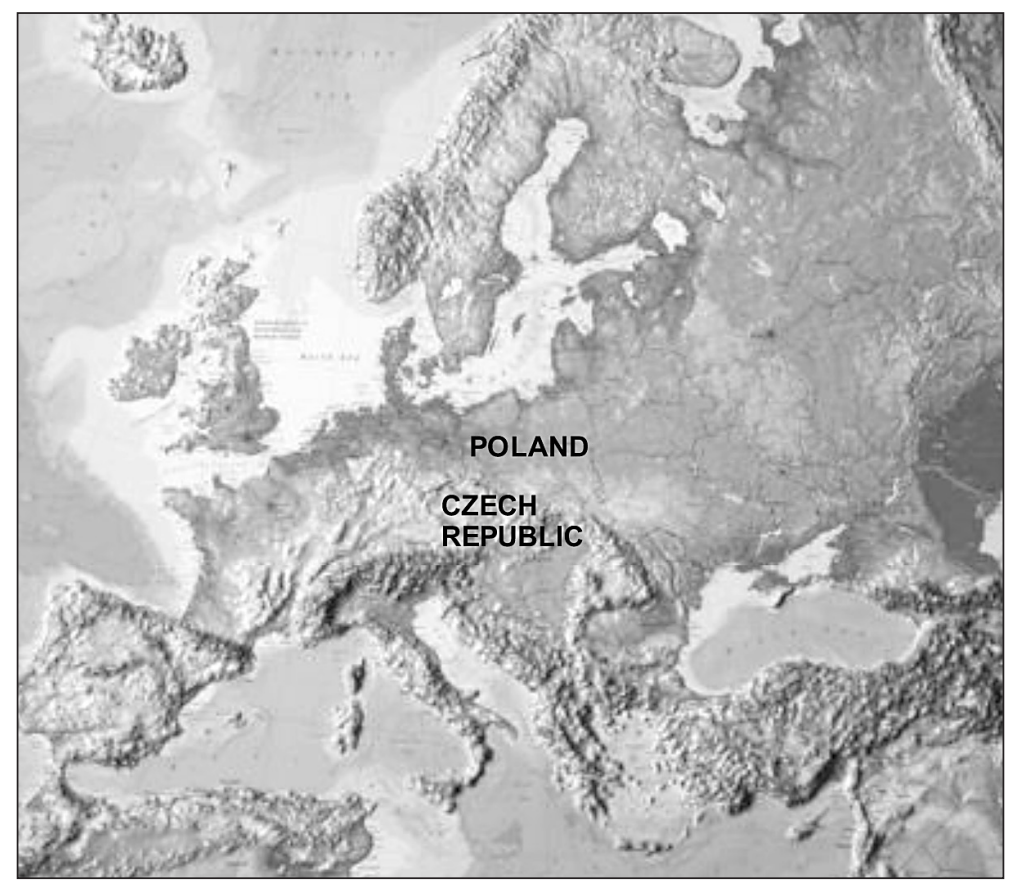

Fig. 1. Location Poland and Czech Republic on the background of Europe 
Additional arguments supporting the idea of owning farming land in Poland are:

- historically established relationship with land perceived not only as economic value, but also as cultural and symbolic value,

- lower taxes and cheaper social insurance [Hełdak et al., 2017].

The source materials used in the article were obtained from the database of European Statistical Office (Eurostat), database of Central Statistical Office in Poland (GUS) and Český statistický úrad (CZSO). The data of European Statistical Office referring to the agricultural structure in Poland are based the results of general agricultural census of 2002 and 2010 adapted to the methodology chosen for European statistical data [Farm Structure Survey...2016, www.ec.europa.eu/eurostat]. Later data is currently not available.

The holding was assumed, in accordance with European Statistical Office, as a single unit, in economic and technical terms, possessing its own management and making agricultural products. In order to assess the scope of transition of structural change statistical methods were used.

Currently, the most commonly used method in comparing the changes is a comparison of an average level of value of individual variables, assigned to a particular holding. Apart from the change in the average value of individual variables, the level of 'good' possessed concentration is usually observed, which is measured by Gini coefficient [Glasser 1962; Binderman 2014].

For research purposes, the Gini coefficient was calculated pursuant to the following formula (1):

$$
G=\frac{\sum_{i=1}^{n}(2 i-n-1) x_{i}^{\prime}}{n^{2} \mu}
$$

where: $x^{\prime} i$-value of the ith observation;

$\mu-$ mean value of all x'i observations.

The Gini coefficient is used as a main measurement tool within information systems of large commercial institutions with international reach, ones which collect data on the levels of differentiation in access to a specific good in individual subpopulations. Moreover, it also allows to plot the trend of the process, whether the differentiation does not grow too quickly during the predefined periods within a specific group of objects [Zawistowski et al., 2016].

According to the authors' noting the Gini coefficient is the most well-known and most widely used coefficient in the studies of income inequality [Zawistowski et al., 2016; Hoffmann and Bradley, 2007; Barnett et al., 2005].

Literature presents numerous measurement proposals, including the so-called AR coefficient, based on the differentiation curve of two distributions with the same carrier. In practical terms, it is used for two structures that are a notional generalisation of the Lorenz curve [Gastwirth, 1971; Arnold, 1987; Glasser, 2012; Binderman and Szczesny, 2016], and the AR coefficient is calculated with use of a formula similar to that used to determine the Gini coefficient. In order to define this measure more precisely, it should be assumed that we are dealing with two structures described with use of structural vectors $\mathrm{p}$ and $\mathrm{q}(2)$, where:

$$
\begin{aligned}
& p=\left(p_{1, \ldots} p_{k}\right) i q=\left(q_{1, \ldots} q_{k}\right), p_{1}, q_{1} \geq \\
& \geq 0, i=1, \ldots k \text { oraz } \sum_{i=1}^{k} p_{i=1}, \sum_{i=1}^{k} p_{i}
\end{aligned}
$$

Moreover, it should be emphasised that in practical cases, the coordinates of each of the analysed structures correspond either to the relative amount (frequency) of the objects in the analysed population or to the share of the given goods assigned to the objects in the analysed population, grouped according to the predefined, separate value ranges of a strictly defined variable, which is marked with the symbol A to determine attention. On the other hand, objects are grouped according to the value ranges, which are marked with the symbols a1, a2, ..., ak in the general notation to determine attention. The a1, a2, .., ak values may (but not necessarily) have a specific order, e.g. a1 $<$ a $2<\ldots<$ ak, where $<$ refers to the relation of the adopted preference.

The Lorenz curve is a graphic method of analysing the concentration strength. The concentration curve is drawn based on: accumulated structural coefficients (percentages) of the units (amount) on the abscissa (0X) and the accumulated total values of an attribute (centres of class ranges, variants of their number) on the ordinate $(0 \mathrm{Y})$.

The Lorenz curve is used in economics and ecology to describe the inequality in wealth or size. The Lorenz curve is a function of the cumulative proportion of ordered individuals mapped onto the corresponding cumulative proportion of their size. Given a sample of $\mathrm{n}$ ordered 
individuals with $x_{i}^{\prime}$ the size of individual $i$ and $x_{1}^{\prime}<x_{2}^{\prime}<\cdots<x_{n}^{\prime}$, then the sample Lorenz curve is the polygon joining the points, $(\mathrm{h} / \mathrm{n}, \mathrm{Lh} / \mathrm{Ln})$, where $\mathrm{h}=0,1,2 \ldots \mathrm{n}, \mathrm{L} 0=0$, and $L_{h}=\sum_{i=1}^{h} x_{i}^{\prime}(3)$.

$$
L(y)=\frac{\int_{0}^{y} x d F(x)}{\mu}
$$

where $F(y)$ is the cumulative distribution function of ordered individuals and $\mu$ is the average size.

\section{CHANGES IN THE STRUCTURE OF AGRICULTURAL LAND USE ON THE TERRITORY OF POLAND AND THE CZECH REPUBLIC}

\section{General characteristics of agricultural land}

The pace of change in the area of utilised agricultural land and in its structure is greater in those countries, where similarly to Poland, the number of factors connected with the membership in the EU is a political and economic novelty [Poczta, Kołodziejczak 2004, Poczta (ed.) 2013]. The area of utilised agricultural land in holdings is the subject to significant fluctuations in all countries of the Visegrad Group (table 1), which has been triggered by systemic transformation and accession to the European Union structures.

The information presented above shows a substantial decrease in the area of the utilised agricultural land; however, not in all Visegrad Group countries. In Poland and in the Czech Republic there was a noticeable decline in the area of utilised agricultural land in 2013 in comparison to 2005. Nevertheless, the percentage of change is minor.

In Poland, the changes were influenced by the farming policy of the European Union, including financial support for the farmers, who actually farm the agricultural land. The farmers who only posses the ownership title and do not deal with agricultural production (set the land aside) are not entitled to the financial support.

The interpretation of these data demonstrates that after the accession into the European Union, the interest in unused agricultural land increased, not only as a result of fear of losing direct subsidies, but also due to the profits brought by land used for agricultural production [Central Statistical Office, 2013].

A small change is noticeable in the very structure of agricultural land use in the Czech Republic. One may assume that the borderlines of urban area and agricultural use are more stable.

In Poland, all utilised agricultural land of the I-III soil quality class and utilised agricultural land of the IV-VI organic soil quality class are under protection. The remaining utilised agricultural land and land located within administrative areas of cities are not under legal protection. In 2014, in total, approximately 50.790 ha of utilised agricultural land was converted from agricultural production, but only part of it constitutes the land converted following the Poviat Staroste (Governor)'s resolution. In Poland, an increasing tendency is noted.

In the years 2002-2010, over 40 thousand hectares of agricultural land were withdrawn from agricultural production annually, while in 2010 this surface area increased to 62 thousand hectares. In the years $2002-2010$ a total of 360 hectares of agricultural land were withdrawn, including 28.2 thousand hectares of arable land. In the said period, the large surface area of land designed for purposes other than agriculture might have resulted from numerous investments, e.g. those connected with the organisation of the Euro 2012 European Football Championship in Poland. In the subsequent years, the area of withdrawn land decreased. Then, in 2014, it increased once again to 50790 ha. Part of infertile land is forested;

Table 1. Total area of agricultural land in the Visegrad Group countries in comparison to the country area

\begin{tabular}{|c|c|c|c|c|c|c|c|}
\hline \multirow{2}{*}{ Item } & Country & \multicolumn{2}{|c|}{ Area of utilised agricultural land in holdings in the } & \multirow{2}{*}{$\begin{array}{c}\text { Country area } \\
\text { years }[\mathrm{km}]\end{array}$} & $\begin{array}{c}\text { Share of the agricultural } \\
\text { land in the total area } \\
\text { of the country in } \\
\text { 2005:2013 [\%] }\end{array}$ \\
\cline { 3 - 7 } & & 2005 & 2007 & 2010 & 2013 & As for 2012 eurostat & $45: 44$ \\
\hline 1 & Czech Republic & 3557790 & 3518070 & 3483500 & 3491470 & 78865 & $46: 50$ \\
\hline 2 & Hungary & 4266550 & 4228580 & 4686340 & 4656520 & 93024 & $47: 46$ \\
\hline 3 & Poland & 14754880 & 15477190 & 14447290 & 14409870 & 312679 & $38: 39$ \\
\hline 4. & Slovakia & 1879490 & 1936620 & 1895500 & 1901610 & 49036 & \\
\hline
\end{tabular}

Source: own elaboration based on EUROSTAT (2005-2018) 
however, the private owners of farms remain the main initiators of agricultural land use change.

In the Czech Republic, fundamental decisions referring to agricultural activities are regulated by Common Agricultural Policy Act and Agricultural Stock Act. "Agricultural Land Stock" carries out its activities following the regulations of the latter; the regulations on land conversion from the stock (after obtaining the approval of an appropriate administrative body) are provided there, too.

\section{Analysis of Change in the Area and Land Structure of Agricultural Holdings}

Farming in Poland is characterised by a very large fragmentation, although an increase of utilised agricultural area per one holding is observed. In 2002, an average area of a holding was 5.8 ha and in 2013 - it was already 10.2 ha. In 2013, slightly more than half of holdings in Poland use more than 5.0 ha of the utilised agricultural land, yet an increase in area of agricultural holdings has been noticeable, in comparison to 2005.

In the Czech Republic the largest share is for holdings in 5.00 to 19.99 ha group and it has increased in comparison to 2005 , as well (Table 2).

The increase of the number of holdings in the agricultural area above 100 ha is a positive phenomenon in both countries (Table 3 ).

The number of agricultural holdings has been systematically decreasing in both the European Union and Poland (on average approximately $3 \%$ a year) because of the land concentration and production concentration. This phenomenon substantially influences the agricultural land market. In the Czech Republic, a significant decrease of agricultural holdings of the area below 5.00 ha to the benefit of larger area holdings (from 24.8 thousand of agricultural holdings in 2003 to 3.3 thousand in 2010) was a positive phenomenon between 2003 and 2010. The percentage share of agricultural holdings in accordance with agricultural area groups also looks better in the Czech Republic, where the transition changes in 2003-2010 resulted in the decrease of share of the number of smaller holdings to the benefit of groups gathering larger area holdings. In the group of holdings above 5.00 ha, the number of holdings dropped by $39.9 \%$ whereas in Poland the

Table 2. The number of agricultural holdings by agricultural area in $2005-2013$

\begin{tabular}{|c|c|c|c|c|c|c|c|c|}
\hline \multirow[b]{2}{*}{ Item } & \multirow[b]{2}{*}{ Country } & \multirow[b]{2}{*}{ Year } & \multicolumn{6}{|c|}{ The number of holdings [in thousands]: } \\
\hline & & & Zero ha & $\begin{array}{c}\text { Less than } \\
5.00 \text { ha }\end{array}$ & $\begin{array}{c}\text { from } 5 \text { to } \\
19.9\end{array}$ & $\begin{array}{c}\text { from } 20 \text { to } \\
49.9 \text { ha }\end{array}$ & $\begin{array}{c}\text { from } 50 \text { to } \\
99.9 \text { ha }\end{array}$ & $\begin{array}{c}100 \text { ha or } \\
\text { over }\end{array}$ \\
\hline 1. & \multirow{4}{*}{$\begin{array}{c}\text { Czech } \\
\text { Republic }\end{array}$} & 2005 & 1.07 & 21.31 & 9.09 & 4.37 & 2.15 & 4.26 \\
\hline 2. & & 2007 & 0.91 & 18.93 & 8.53 & 4.46 & 2.31 & 4.26 \\
\hline 3. & & 2010 & 0.29 & 3.24 & 8.13 & 4.37 & 2.42 & 4.42 \\
\hline 4. & & 2013 & 0.29 & 4.58 & 9.55 & 4.73 & 2.46 & 4.63 \\
\hline 5. & \multirow{4}{*}{ Poland } & 2005 & 10.65 & $1,740.22$ & 608.14 & 96.78 & 13.47 & 7.23 \\
\hline 6. & & 2007 & 10.84 & $1,626.44$ & 628.67 & 101.37 & 15.79 & 7.85 \\
\hline 7. & & 2010 & 7.96 & 823.42 & 553.46 & 95.28 & 16.84 & 9.65 \\
\hline 8. & & 2013 & 7.45 & 770.36 & 517.18 & 102.48 & 20.57 & 10.95 \\
\hline
\end{tabular}

Source: own elaboration based on EUROSTAT (2005-2018)

Table 3. The utilised agricultural area in particular area groups

\begin{tabular}{|c|c|c|c|c|c|c|c|c|}
\hline \multirow[b]{2}{*}{ Item } & \multirow[b]{2}{*}{ Country } & \multirow[b]{2}{*}{ Year } & \multicolumn{6}{|c|}{ Utilised agricultural area [in thousand ha]: } \\
\hline & & & Zero ha & $\begin{array}{c}\text { Less than } \\
5.00 \text { ha }\end{array}$ & $\begin{array}{c}\text { from } 5 \text { to } \\
19.9 \\
\end{array}$ & $\begin{array}{c}\text { from } 20 \text { to } \\
49.9 \text { ha }\end{array}$ & $\begin{array}{c}\text { from } 50 \text { to } \\
99,9 \text { ha }\end{array}$ & $\begin{array}{c}100 \text { ha or } \\
\text { over }\end{array}$ \\
\hline 1. & \multirow{4}{*}{$\begin{array}{l}\text { Czech } \\
\text { Republic }\end{array}$} & 2005 & 0 & 33.32 & 93.59 & 137.61 & 149.96 & 3143.30 \\
\hline 2. & & 2007 & 0 & 29.46 & 87.68 & 140.96 & 161.15 & 3098.83 \\
\hline 3. & & 2010 & 0 & 5.81 & 84.98 & 138.18 & 169.36 & 3085.16 \\
\hline 4. & & 2013 & 0 & 83.10 & 98.83 & 147.41 & 171.47 & 3065.45 \\
\hline 5. & \multirow{4}{*}{ Poland } & 2005 & 0 & 2591.51 & 5902.44 & 2788.60 & 900.52 & 2571.81 \\
\hline 6. & & 2007 & 0 & 2724.04 & 6056.45 & 2930.54 & 1058.35 & 2707.80 \\
\hline 7. & & 2010 & 0 & 2277.18 & 5398.13 & 2779.08 & 1145.01 & 3120.90 \\
\hline 8. & & 2013 & 0 & 1880.06 & 5062.71 & 3030.15 & 1393.18 & 3043.78 \\
\hline
\end{tabular}

Source: own elaboration based on EUROSTAT (2005-2018) 
decrease in the same group was only by $10.4 \%$. In both countries, there was an increase of share of holdings in the 5.00-19.99 ha groups; however, much greater changes, considered to be beneficial, were observed in this period in the Czech Republic. In Poland, some change in the number of holdings is also noticeable, although the process is slowed down by the existing structural situation in agriculture during accession into the European Union. In Poland, some changes took place earlier, in the years 2002-2005, when the number of utilised agricultural land holdings decreased from 2,933.2 thousand to 2,733.4 thousand that is by nearly 200 thousand. All the time, however, the changes are considered to be slowed down. According to Pawlak K. and Poczta W (2010), the area structure of the utilised agricultural land holdings is bipolar, where on the one hand we may point at a numerous group of small holdings using traditional farming methods of growing crops and breeding livestock, while on the other hand, large scale farms functioning in accordance with rational economy.

In the Czech Republic, the situation in the number of holdings is much more beneficial, which is a result of the changes undertaken before the systemic transformation, when agricultural holdings were cooperatives and state-owned.

\section{Assessment of Changes in the Structure of Agricultural Holdings}

The basic formulae to measure the concentration and the data presented in Tables 6 and 7 were a basis for the interpretation of the structure of agricultural farms divided into area groups of farms in the Czech Republic and Poland in the years 2003-2010. The number of the agricultural farms was analysed, followed by their total area and finally, the percentage share in specific area groups for the number and area of agricultural farms. The adopted ranges for dividing farms into area groups were 0-2 ha, 2-5 ha, 5-10 ha, 10-20 ha, 30-50 ha, 50-100 ha and over 100 ha.

The calculations pertaining to the concentration of farms in Poland and in the Czech Republic in the years 2003 and 2010, performed with use of the Lorenz curve, are presented in Figures 2A and $2 \mathrm{~B}$. If the given attribute was spread evenly among all units of the population, all the points would be situated on the diagonal of a square with 100 sides. This is why it is called a uniform distribution line. The area of concentration is the area between the uniform distribution line and the Lorenz curve.

The diagrams presented above enable to determine the strength of concentration of the number of agricultural farms in specific area groups. Considering that the concentration area for Poland is much larger in both Figure (1A and 1B) than for the Czech Republic, one should state that the distribution of the analysed attribute is much less uniform in Poland. In the Czech Republic in the
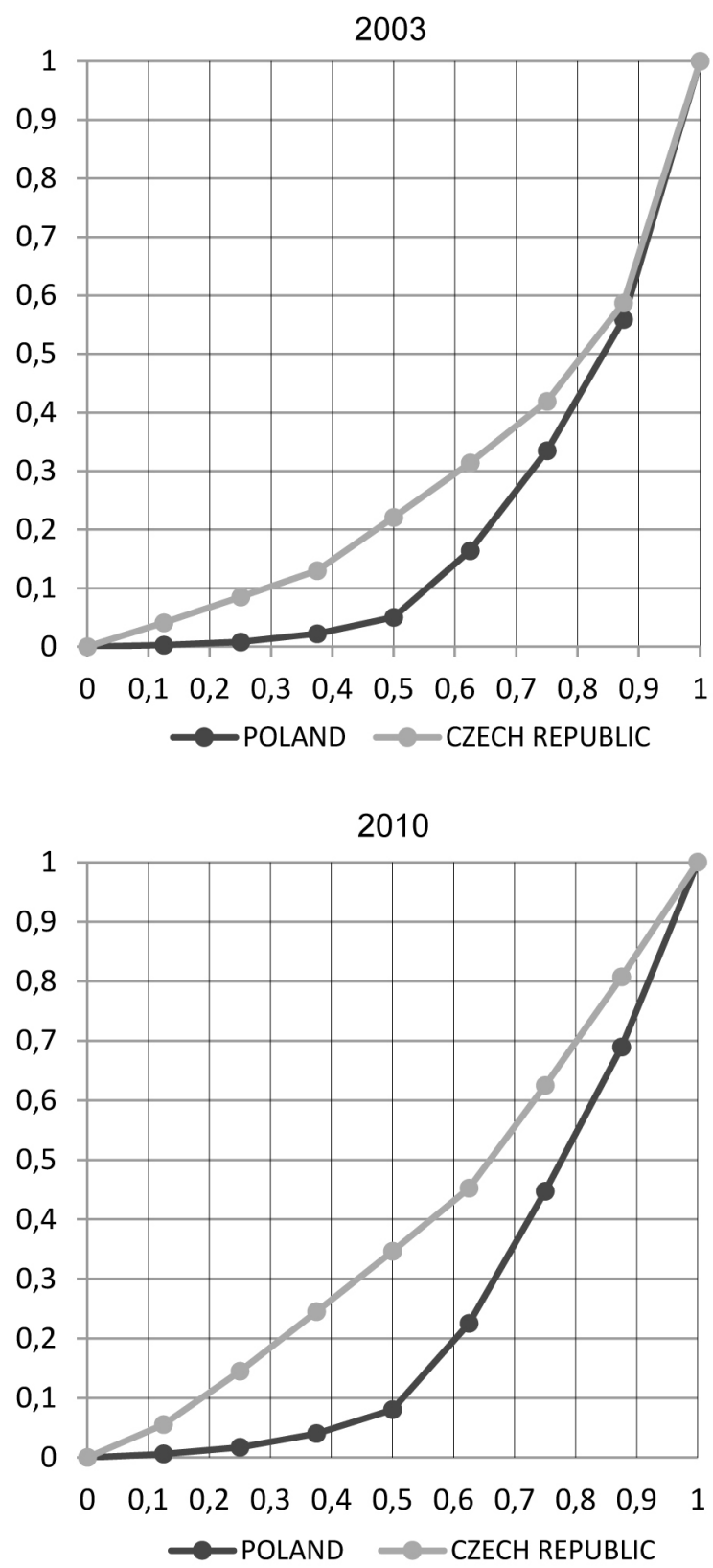

Fig. 2A. Lorenz curve for the number of agricultural farms in area groups in the Czech Republic and Poland in the year 2003

Fig. 2B. Lorenz curve for the number of agricultural farms in area groups in the Czech Republic and Poland in the year 2010 
year 2010 the coefficient approached the uniform distribution line and in 2003 it was not far from the diagonal, either. Comparing the analysed years we may note that there has been a noticeable improvement in the agrarian structure of both countries in terms of the number of agricultural farms in specific area groups.

However, the result of statistical calculations of the concentration coefficient of the attribute: surface area of agricultural farms in area groups (Figure 3A and 3B) in the years 2003 and 2010 for the Czech Republic and Poland is opposite.

The Lorenz curve is noticeably divergent for the farm area structure in the Czech Republic in both analysed years. Here, the distribution is similar to uniform only in Poland. However, uniform concentration does not mean a beneficial structure of agricultural farms, as the idea is to concentrate the area in large-area farms - i.e. in the last group, of a surface area exceeding 100 ha.

The further figures illustrate the percentage distribution of the number and area of agricultural farms in specific area groups (Figure 4 and 5).

The concentration coefficient determined for the percentage share of the number of agricultural farms in area groups in the years 2003 and 2010 revealed that a near-uniform distribution existed in the Czech Republic, while in Poland it was not uniform. This is mainly due to the percentage domination of the number of farms in the smallest area groups $0-2$ and 2-5 ha). In the Czech Republic, a noticeable increasing trend in the share of smaller farms was noted, which was reflected in the Lorenz curve. Noticeable changes in the concentration of this phenomenon in the Czech Republic were also observed with respect to the surface area share of agricultural farms in specific area groups. Currently, a tendency approaching the uniform distribution in specific area groups is also visible.

The concentration strength for the selected indicators of the area structure of agricultural farms in the Czech Republic and in Poland was also measured with use of the Gini coefficient (Table 4).

The interpretation of the Gini coefficient (the surface area between the diagonal and the Lorenz curve) demonstrated that it has the values between $0-1$, provided that the zero value corresponds to completely uniform distribution. It was determined that for the surface area of agricultural farms in the area groups in Czech Republic, the coefficient increased from 0.8021 in
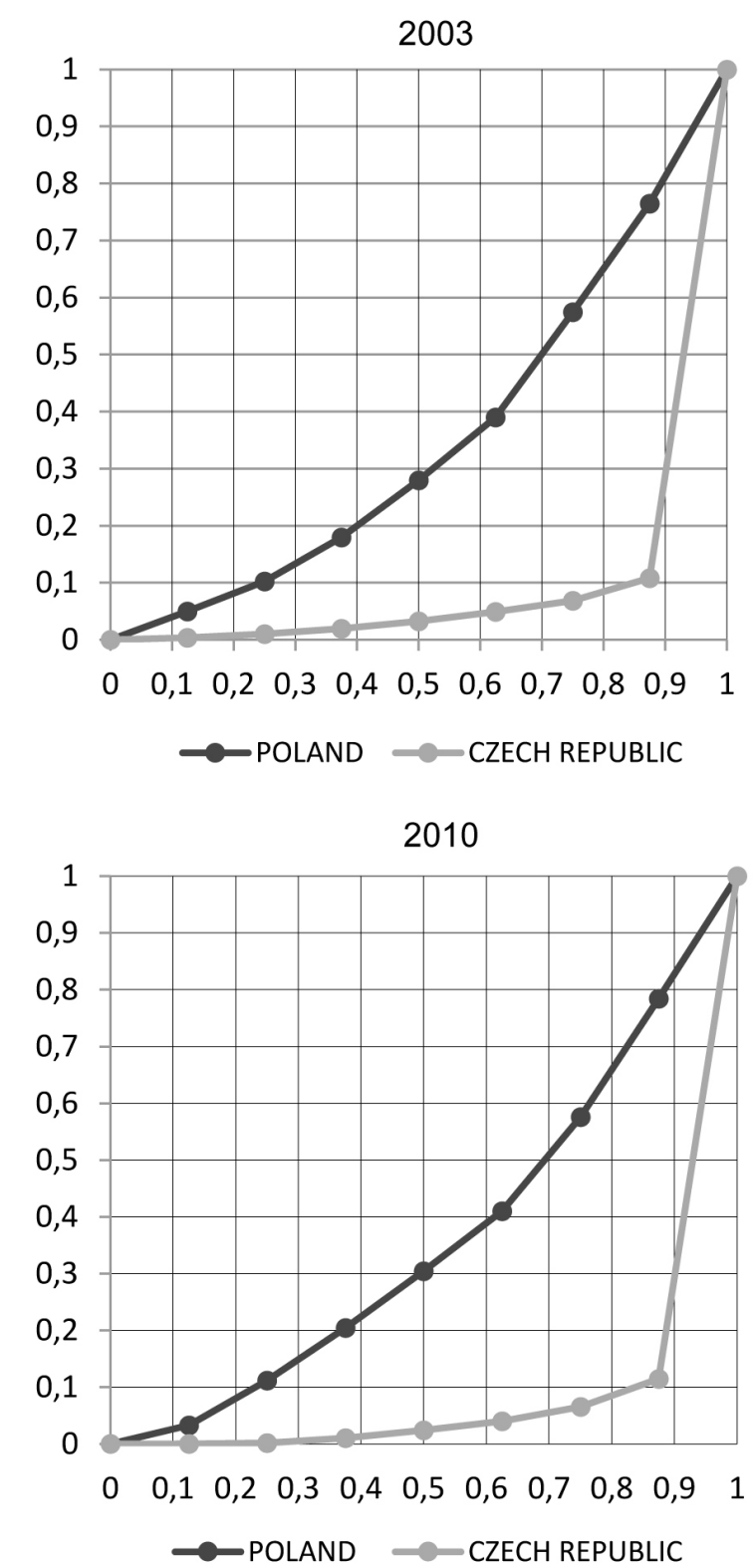

Fig. 3. Lorenz curve for the surface area of agricultural farms in area groups in the Czech Republic and Poland in the year 2010

Fig. 3A. Lorenz curve for the surface area of agricultural farms in area groups in the Czech

Republic and Poland in the year 2003

2003 to 0.8107 in 2010 , which means a growing inequality in the distribution. In the same period, the coefficient for the surface area of agricultural farms in Poland decreased from 0.2897 in 2003 to 0.2692 in 2010 . Such lower coefficient for Poland also proves that the distribution in terms of surface area of agricultural farms has become more uniform. On the other hand, the Gini coefficient calculated for the number of farms in both countries has decreased. Similarly, the coefficient determined for the percentage share of the number 


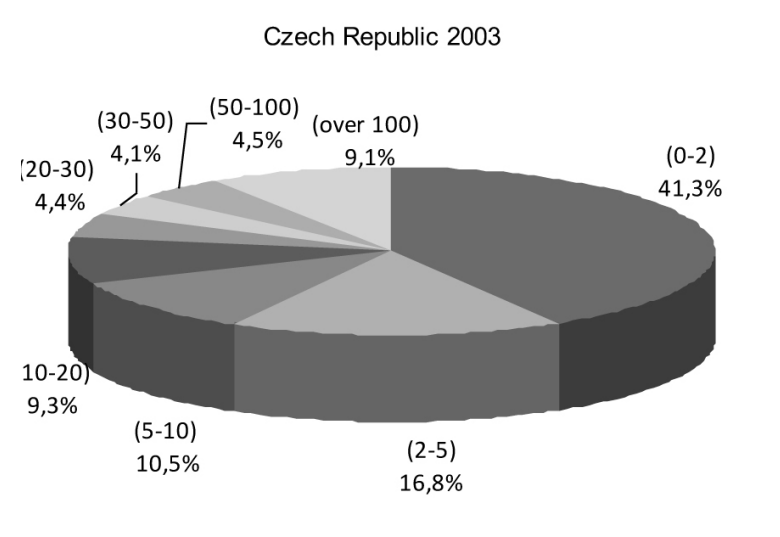

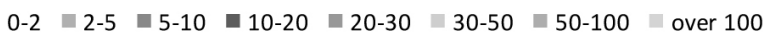

Czech Republic 2010

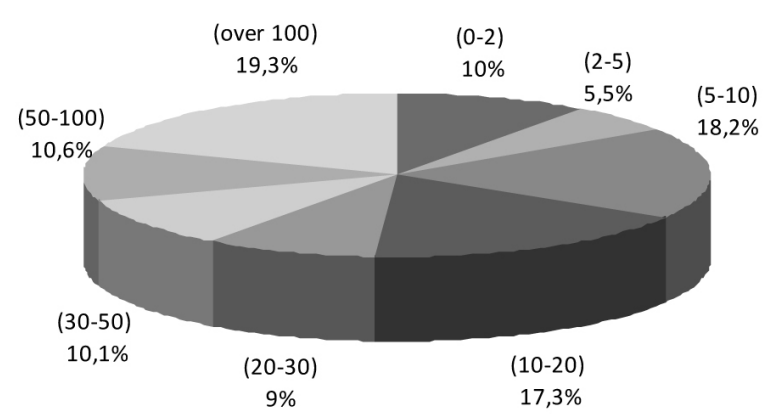

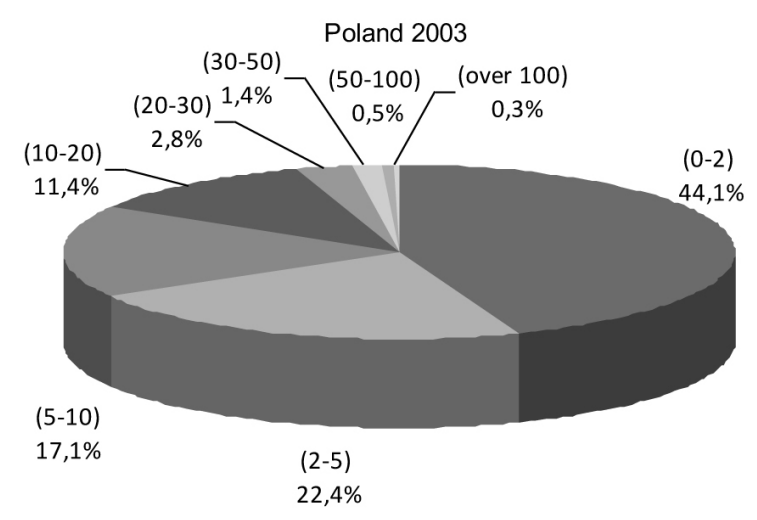

$\square$ 0-2 $=2-5=5-10 \square 10-20=20-30=30-50=50-100=$ over 100

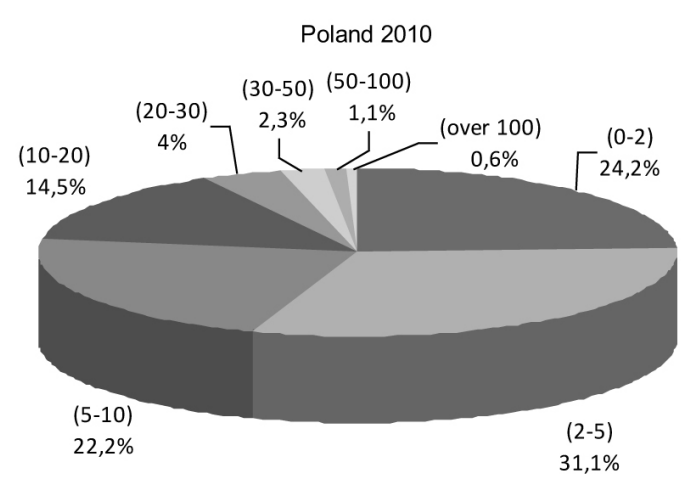

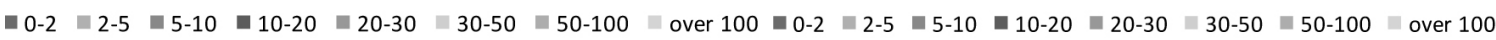

Fig. 4. The structure of holdings [\%] in Czech Republic and Poland in years 2003 and 2010

of farms is decreasing (from 0.5898 to 0.4990 for Poland and from 0.4258 to 0.2062 for the Czech Republic), as for the surface area of farms in specific area groups. Here, the coefficient for Czech Republic has decreased noticeably, from 0.8030 to 0.2062 , as a result of the increased share of surface area of farms in smaller area groups.

\section{CONCLUSIONS}

The Czech Republic and Poland have different structure of agricultural holdings. In Poland, the structure is still fragmented - in 2010 only $21.1 \%$ of the agricultural holdings area was located in the area group above 100 ha, whereas in the Czech Republic $88.6 \%$ was located in the larger area group.

In Poland, agricultural holdings are characterised by worse competence of land resource location, which is envisaged by a large number of farms (the majority are still farms below 5 ha area - more than $50 \%$ of total number). In the Czech Republic the share is equal in particular area group; however, the largest number of holdings is the largest area group (19\%).
In Poland, a large share of land resources in used by small agricultural farms, which - lacking production specialisation - are less competitive in the market, as compared to large scale subjects in the Czech Republic.

On the basis of the Lorenz curve, it was determined that the concentration of the number of agricultural farms in the area groups adopted for the purposes of analysis was much less uniform in Poland than in the Czech Republic. However, in both countries there is a noticeable improvement in the distribution of the number of farms, and, in Poland also, indirectly, the agrarian structure improved in the years 2003-2010.

As far as the structure of farm area is concerned, the Lorenz curve for the Czech Republic is noticeably divergent from the diagonal, which means that the area of farms is concentrated in large agricultural farms.

The analysis of the Gini concentration coefficient has revealed that its value decreased in the years 2003-2010 in nearly all cases, which means a tendency to approach the uniform distribution of the analysed phenomena. An increase in the coefficient 

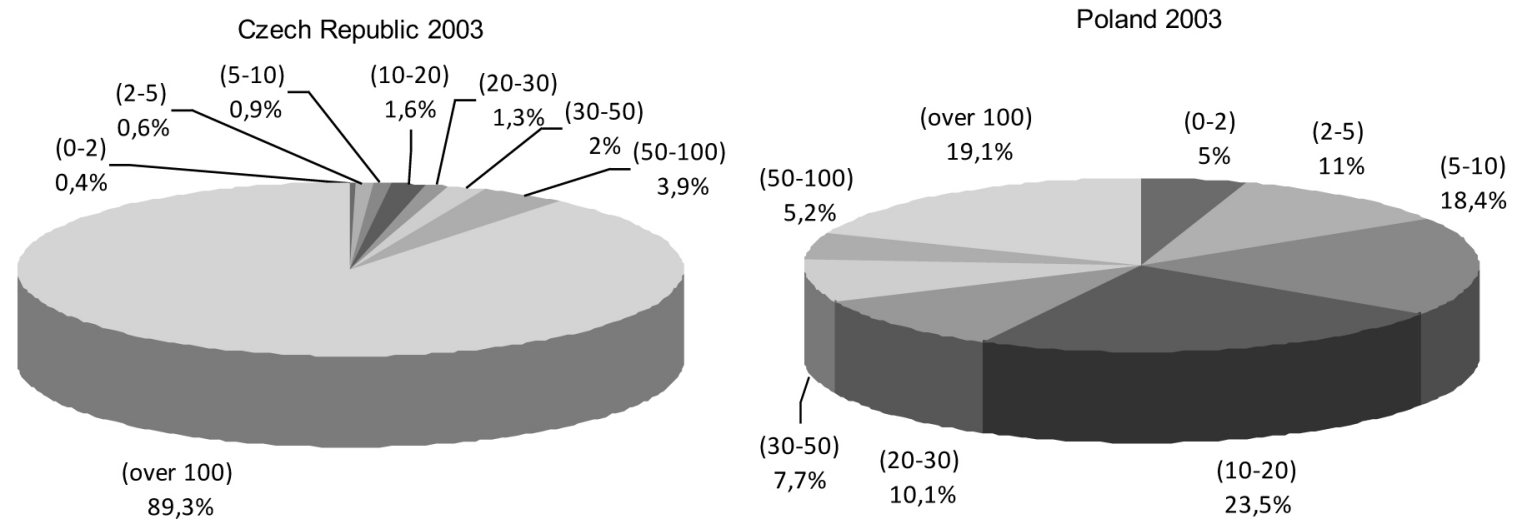

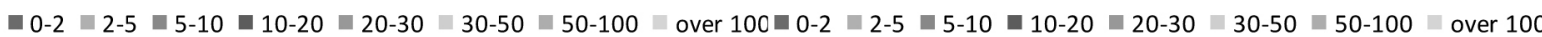
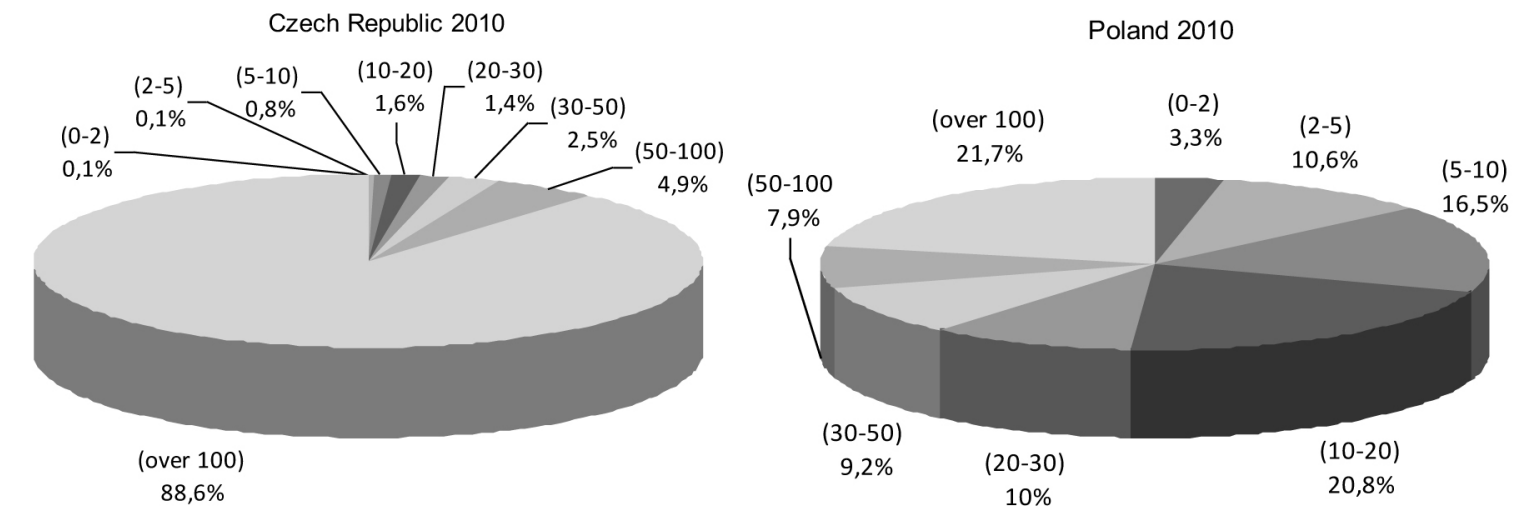

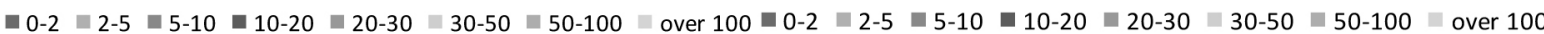

Fig. 5: The structure of land use [\%] in Czech Republic and Poland in years 2003 and 2010

Table 4. Collation of Gini coefficient (according to data from tab. 6 and 7) in Poland and Czech Republic in 2003 and 2010

\begin{tabular}{|c|c|c|c|c|}
\hline \multirow{3}{*}{ Gini coefficient } & \multicolumn{4}{|c|}{ Country: } \\
\hline & \multicolumn{2}{|c|}{ Poland } & \multicolumn{2}{|c|}{ Czech Republic } \\
\hline & 2003 & 2010 & 2003 & 2010 \\
\hline Number of agricultural land & 0.5901 & 0.4981 & 0.4267 & 0.2033 \\
\hline Area of agricultural land & 0.2897 & 0.2692 & 0.8021 & 0.8107 \\
\hline Structure of holdings & 0.5898 & 0.4990 & 0.4258 & 0.2062 \\
\hline Structure of land use & 0.2900 & 0.2698 & 0.8030 & 0.8105 \\
\hline
\end{tabular}

was observed only for the surface area of agricultural farms in area groups in the Czech Republic, from 0.8021 in 2003 to 0.8107 in 2010 , which means a simultaneous growth of inequality in that period.

\section{REFERENCES}

1. Act of 10th February of 2017 Regulations introducing the Act on the National Support Centre for Agriculture (Journal of Laws of 2017, item 623).

2. Arnold, B.C. 1987. Majorizationand the Lorenz Or- der. A Brief Introdaction. Lecture Notes in Statistics 43, Springer-Verlag, Berlin.

3. Balej, M., Andel, J. 2008) Land use changes and environmental stress accounting (case study from northwestern part of the Czech-German borderland. Journal of Geography and Regional Planning 2008 Vol. 1(5), pp. 097-109, from: https://www. researchgate.net/publication/228359648 Land use_changes_and_environmental_stress_accounting_case_study_from_northwestern_part_of_the Czech-German borderland

4. Barnett, R.A, Ziegler, M.R., Byleen, K.E. 2005. College Mathematics R.A. for Business, Econom- 
ics, Life Sciences, and Social Sciences, 10th ed., Prentice-Hall, Upper Saddle River, 2005.

5. Bičík, I., Štěpánek, V. 1994. Post-war changes of the land-use structure in Bohemia and Moravia: Case study Sudetenland. GeoJournal. Vol. 32. No. 3. p. 253-259, from: https://link.springer.com/ article $/ 10.1007 \% 2 \mathrm{FBF} 01122117$

6. Binderman, Z., Koszela, G., Szczesny, W. 2014. Zmiany w strukturze gospodarstw rolnych w krajach Unii Europejskiej w latach 2003-2010 (aspekty metodyczne), [Changes in the structure of agricultural holdings in the European Union in 2003-2010 (methodical aspects)]. Zeszyty Naukowe Szkoły Głównej Gospodarstwa Wiejskiego w Warszawie Problemy Rolnictwa Światowego tom 14 (XXIX). zeszyt 3, 15-26 [In Polish].

7. Binderman, Z., Szczesny, W. 2016. Ocena zmiany w strukturze obszarowej gospodarstw rolnych w Polsce na tle nowych państw UE (aspekty metodyczne), [Assessment of change in the area structure of agricultural holdings in Poland compared to new EU countries (methodological aspects)]. OPITIMUM Studia Ekonomiczne. DOI: 10.1529/ ose.2016.02.80.07, [In Polish].

8. Český statistický úrad (CZSO). 2016. Retrieved from: https://www.czso.cz/.

9. Druga, M., Faltan, V. 2014. Influences of environmental drivers on land cover structure and its long-term changes: a case study of the villages of Malachov and Podkonice in Slovakia. Moravian Geographical Reports Vol. 22, 3/2014, from: https://www.geonika.cz/EN/research/ENMGRClanky/2014_3_DRUGA.pdf

10. European Statistical Office. Farm Structure Survey. Available from: www.ec.europa.eu/eurostat.

11. Environmental Protection. Environment. 2014. Central Statistical Office in Poland (GUS). Warszawa.

12. Farm Structure Survey. Retrieved from www. ec.europa.eu/eurostat.

13. Faltejsková, O., Dvořáková, L., Hotovcová, B. 2016. Net promoter score integration into the enterprise performance measurement and management system - a way to performance methods development. E\&M Economics and Management, volume XIX, 1/2016, 93-106. DOI: 10.15240/ tul/001/2016-1-007

14. Glasser, G.J. 2012. Variance Formulas for the Mean Difference and Coefficient of Concentration. Journal of the American Statistical Association 2012 57:299, 648-654, DOI: 10.1080/01621459.1962.1 0500553

15. Główny Urząd Statystyczny w Polsce (GUS). 2016. Central Statistical Office in Poland (GUS) Retrieved, from: http://www.gus.pl/

16. Hietel, E., Waldhardt, R., Otte, A. 2005. Linking socio-economic factors. Environment and land cover in the German Highlands. 1945-1999. Journal of Environmental Management. Vol. 75. No. 2., p. 133-143, from: https://doi.org/10.2478/mgr2014-0016

17. Hełdak, M., Stacherzak, A., Kucher, A. 2017. Analysis of the changes in transaction prices of agricultural land in Poland. Hradec Economic Days 7 2017 p. 287-295, from: http://fim2.uhk.cz/hed/data/ proceedings_17.pdf

18. Hoffmann, L.D. and Bradley, G.L. 2007. Calculus for Business, Economics, and L.D. the Social and Life Sciences, 9th ed., McGraw Hill, New York, 2007.

19. Gastwirth, J.L. (1971). A general definitione of the Lorenz curve. Econometrica, 39. from: https://econpapers.repec.org/article/ecmemetrp/ v_3a39_3ay_3a1971_3ai_3a6_3ap_3a1037-39.htm

20. Glasser, G.J., 1962. Variance formulas for the mean difference and coefficient of concentration. J. Am. Statistic. Assoc. 57, 648-654. DOI: 10.1080/01621 459.1962.10500553

21. Jarmołowicz, W., Piatek, D. 2013. Economy of Poland, the Czech Republic and Hungary after 20 years of transition. Transformation in Business \& Economics 12(2B), 293-304.

22. Križan, F., Biliková, K., Kita, P., Siviček T. 2016. Transformation of retailing in post-communist Slovakia in the cintext of globalization. E\&M Economics and Management, volume XIX, 1/2016, 148-164, DOI: 10.15240/tul/001/2016-1-011

23. Lerman, Z., Csaki, C., Feder, G. 2002. Land Policies and Evolving Farm structures in Transition Countries. Policy Research Working Paper 2794. The World Bank Development, from: http://documents.worldbank.org/ curated/en/885151468746704912/120520322 20041117152044/additional/multi0page.pdf

24. Lipský, Z. 1995. The changing face of the Czech rural landscape. Landscape and Urban Planning. Vol. 31. No. 1-3. p. 39-45, from: https://doi.org/10 .1016/0169-2046(94)01036-8

25. Lorincz, R., Balazs, K. 2003. Historical land use analysis and landscape development investigations for devising sustainable land use structure. In Mander, Ü., Antrop, M. [eds.]: Multifunctional Landscapes Volume III. Continuity and Change. Southhampton. Boston. WIT Press. pp. 243-261. DOI: https://doi.org/10.2478/mgr-2013-0004

26. Opršal, Z., Šarapatka, B., Kladivoz, P. 2013. Landuse changes and their relationships to selected landscape parameters in three cadastral areas in Moravia (Czech Republic). Moravian Geographical Reports. Vol. 21. 1/2013. p. 41-50, from: https://www. geonika.cz/EN/research/ENMGRClanky/2013_1_ OPRSAL.pdf 
27. Pawlak, K., Poczta, W. 2010. Potencjał polskiego rolnictwa pięć lat po akcesji do UE jako przesłanka jego konkurencyjności [Potential of Polish agriculture five years after the accession to the EU as a condition of its competitiveness], Wieś i rolnictwo. $\mathrm{Nr}$ 1(146)2010, from: http://kwartalnik.irwirpan. waw.pl/dir_upload/photo/d30ffb488c2f3bcf8606eb601a63.pdf [In Polish].

28. Prutis, S. (2006). Struktury gospodarcze państwowej własności rolniczej [Economic structures of state agricultural property], [w:] Prawo rolne. A. Stelmachowski (red.). Warszawa 2006, pp. 205 [In Polish].

29. Poczta, W., Kołodziejczak, M. 2004. Potencjał produkcyjny rolnictwa polskiego i efektywność gospodarowania $\mathrm{w}$ aspekcie integracji $\mathrm{z}$ Unią Europejską, [The production potential of Polish agriculture and the effectiveness of management in the aspect of integration with the European Union], Wydawnictwo Akademii Rolniczej w Poznaniu. Poznań [In Polish].

30. Poczta W. (red.). 2013. Gospodarstwa rolne w Polsce na tle gospodarstw Unii Europejskiej - wpływ WPR [Agricultural holdings in Poland against the background of EU farms - the impact of WPR]. Główny Urząd Statystyczny. Warszawa, from: https://stat. gov.pl/cps/rde/xbcr/gus/RL_Gospodarstwa_rolne_ na_tle_internet. pdf [In Polish],

31. Rumpel, P., Slach, O., Koutsky, J. 2013. Shrinking cities and governance of economic regeneration: The case of Ostrava. E\&M Economics and Management, volume 16(2), 113-128.
32. Urbšiene, L. 2013. The impact of globalisation to transitional economies: Evidence for Lithuania. Transformation in Business \& Economics 12(1), 140-162, from: https:/www.researchgate.net/publication/289769165_The_impact_of_globalisation to_transitional_economies_Evidence_for_lithuania

33. Sadowski, A. 2009. Własność a użytkowanie gruntów rolnych. Zarys tendencji rozwojowych [Ownership and use of agricultural land. Outline of development trends], Białystok, pp. 300.

34. Sarris, A.H., Doucha, T., Mathijs, E. 1999. Agricultural restructuring in central and eastern Europe: implications for competitiveness and rural development. European Review of Agricultural economics 26 (3), from: ftp://ftp.soc.uoc.gr /students/niksem/ com_4sarris.pdf

35. Swinnen, J.F.M. 2001. Implications of EU enlargement for Agri-food Markets and Policy. Materials for the conference Outlook for Agriculture. Agribusiness and the Food Industry in Central and Eastern Europe at Budapest 18th of May 2001. Hungary.

36. Zegar, J.St. 2013. Kwestia bezpieczeństwa żywnościowego a ekonomia [The issue of food security and economics], IX Kongres Ekonomistów Polskich. Warszawa [In Polish].

37. Zawistowski, Z.J., Szczesny, W., Borkowski, B., Kozera, R., Shachmurove, Y. 2016. Alternative Method of Measuring Concentration, Appl. Math. Inf. Sci. 10, No. 1, 11-19. 